\title{
Human Lymphocyte Mitogen of Microbial Origin and Cell-Cell Interaction among Leukocytes in Response to the Mitogen
}

\author{
Yasuo Seto, ${ }^{*}$ Kunio Oishi and Ko AIDA \\ Institute of Applied Microbiology, The University of Tokyo, \\ 1-1-1 Yayoi, Bunkyo-ku, Tokyo 113, Japan \\ Received February 5, 1987
}

\begin{abstract}
Mitogenic substances on human peripheral blood mononuclear leukocytes were screened from culture filtrates of microorganisms newly isolated from soil and sea water by measuring $\left[{ }^{3} \mathrm{H}\right]-$ thymidine incorporation into the cells. Strong mitogenic activity was found in marine bacteria, particularly in marine vibrios. These mitogen samples exhibited neither hemagglutinating activity nor leukoagglutinating activity. They could scarcely stimulate murine lymphocytes.

Cell-cell interaction among leukocyte subsets in response to a bacterial mitogen was investigated using the most powerfully mitogenic sample (culture filtrate of strain $\mathrm{H}$ 52-2). A slight decrease in the mitogen response was observed on depletion of plastic surface adherent cells. Separation of $\mathrm{T}$ and non-T cells from each other by erythrocyte-rosette sedimentation resulted in a markedly diminished mitogen response. Considerable restoration of the mitogen response was obtained when $\mathrm{T}$ cells were mixed with mitomycin C-treated adherent cells or mitomycin C-treated non-T lymphocytes, or when non- $\mathrm{T}$ lymphocytes were mixed with mitomycin $\mathrm{C}$-treated $\mathrm{T}$ cells.
\end{abstract}

Mitogens, which induce transformation in a polyclonal range of lymphocytes, are useful tools for the fundamental studies in immunology, i.e., studies on the mechanism of lymphocyte activation or in vitro diagnosis of immune function. Some plant lectins ${ }^{1)}$ are known to be mitogenic, and classified with respect to animal species specificity and proliferating cell specificity. Microorganisms were also found to produce mitogens such as lipopolysaccharides $^{2)}$ (LPS) and the lymphocytosis-promoting factor of Bordetella pertussis. ${ }^{3)}$ Most of these mitogens, however, show high species specificity and act only on rodent lymphocytes. Therefore, clinical studies for elucidation of the human immune function lag far behind those concerning rodents.

The screening of mitogenic substances from microorganisms in nature has not yet been undertaken systematically. Recently, Ariizumi et al. reported the distribution of strains producing mitogens for murine lymphocytes among nonpathogenic microorganisms, and precipitate of the culture filtrate of Pseudomonas vesicularis IAM 12105. ${ }^{4)}$ We have tried to obtain new mitogens for human lymphocytes from microorganisms and found much mitogenic activities in marine bacteria. In this paper, we describe the distribution of mitogen producers among newly isolated microorganisms and the cell-cell interaction mechanism of human leukocytes in response to the most potent microbial mitogen obtained.

\section{MATERIALS AND METHODS}

Materials. Lymphoprep and Ficoll-Paque were purchased from Nyegaard \& Co. (Oslo, Norway) and Pharmacia (Uppsala, Sweden), respectively. Lipopolysaccharide (E.coli serotype 0111: $\mathrm{B}_{4}$, phenol extract), neuraminidase (Type V) and concanavalin $A$ (Con.A) (Type IV) were purchased from Sigma Chemical Co. (St. Louis). RPMI-1640 medium and fetal calf serum (FCS) were obtained from Grand Island Biological Co. (Grand Island, N.Y.). Pokeweed mitogen (PWM) and phytohemagglutinin (PHA) were obtained from E. Y.

* Present address: National Research Institute of Police Science, Sanban-cho, Chiyoda-ku, Tokyo 102, Japan. 
Laboratory and Difco (Detroit, Michigan), respectively. $\left[{ }^{3} \mathrm{H}\right]$-Thymidine $(20.0 \mathrm{Ci} / \mathrm{mmol})$ was purchased from New England Nuclear (Boston, Mass.). Sheep blood was obtained from Japan Biosupply Center (Tokyo). All other chemicals were of analytical reagent grade.

Preparation of murine lymphocytes. C57BL/6 mice (4 12 week old, female) were purchased from Charles River Japan, Inc. (Atsugi). Their spleens were removed and teased out with forceps under sterile conditions. Free splenic cells were incubated at $37^{\circ} \mathrm{C}$ for $5 \mathrm{~min}$ in a solution containing $0.01 \mathrm{M}$ Tris(hydroxymethyl)aminometane and $0.83 \%$ ammonium chloride ( $\mathrm{pH} 7.4$ ) to lyse contaminating erythrocytes (ACT treatment). Thymic cells were obtained as described for splenic cells.

Preparation of human mononuclear leukocytes. Human mononuclear leukocytes (MNL) were isolated from peripheral blood as described by Böyum. ${ }^{5)}$ Venous blood from healthy adults was heparinized $(100 \mathrm{IU} / \mathrm{ml}$ blood $)$ and then left at room temperature for $10 \mathrm{~min}$. Five $\mathrm{ml}$ of defibrinated blood was diluted twice with Dulbecco's phosphate-buffered saline $(-)^{6)}$ (PBS) and then layered upon $4 \mathrm{ml}$ of Lymphoprep, followed by centrifugation $(400 \times g)$ at room temperature for $30 \mathrm{~min}$. MNL at the interface were collected and washed with PBS by centrifugation $(250 \times g, 5 \mathrm{~min})$.

Assay for mitogenic activity. Mitogenicity was assayed by measuring $\left[{ }^{3} \mathrm{H}\right]$-thymidine uptake according to the method of Janossy and Greaves. ${ }^{7)}$ Isolated human MNL were suspended in RPMI-1640 medium supplemented with $10 \%$ human serum, $0.2 \% \mathrm{NaHCO}_{3}$ and $0.01 \%$ kanamycin, at a concentration of $5.0 \times 10^{5}$ living cells per $\mathrm{ml}$. Two hundred $\mu$ l of this suspension was applied to each well of a Microtest II plate (Falcon, Oxnard, Ca.), followed by culturing at $37^{\circ} \mathrm{C}$ in a humidified $\mathrm{CO}_{2}$ incubator under a flow of $5 \% \mathrm{CO}_{2}$ in air. Five $\mu \mathrm{l}$ of a mitogen sample and $0.25 \mu \mathrm{Ci}$ of $\left[{ }^{3} \mathrm{H}\right]$-thymidine were added to the culture at $0 \mathrm{hr}$ and $48 \mathrm{hr}$, respectively. After a further $24 \mathrm{hr}$ culture, the cells were harvested on a glass fiber filter (Harvester Filter, Labo Science, Tokyo) and dried up. The radioactivity incorporated into the cells was measured with Packard 3255 liquid scintillation counter (Packard, Downers Grove, Illinois). The mean counts per minute $(\mathrm{cpm})$ were determined for triplicate cultures. Mitogenic activity is expressed as a stimulation index (SI), which is the ratio of the radioactivity incorporated into cells in the presence of a mitogen sample to that in its absence. The average SI value (aSI) of a mitogenic sample was calculated with the following equation:

$$
\log (\mathrm{aSI})=(1 / n) \sum(\log \mathrm{SI} \mathrm{j})
$$

where SIj is the SI in a mitogenic assay for each MNL donor and $n$ is the number of assays. In the experiment with fractionated cells described below, the average radioactivity incorporated into cells $(\mathrm{aC})$ was calculated with the following equation:

$$
\log (\mathrm{aC})=(1 / n) \sum(\log \mathrm{Cj})
$$

where $\mathrm{Cj}$ is the radioactivity in each mitogenic assay and $n$ is the number of assays.

The conditions for the mitogen assay for murine lymphocytes were identical to those for human MNL except for the cell concentration $\left(2.5 \times 10^{6}\right.$ cell per $\left.\mathrm{ml}\right)$ and the serum used (FCS).

Fractionation of human mononuclear leukocytes. Human thymus-derived lymphocytes ( $\mathrm{T}$ cells) were prepared according to the erythrocyte-rosette (E-rosette) method of Jondal et $a l^{8)}$ and Galili and Schledinger ${ }^{9)}$ with some modification. Sheep red blood cells (SRBC) were treated with neuraminidase (final, 0.1 units $/ \mathrm{ml}$ ) at $37^{\circ} \mathrm{C}$ for $30 \mathrm{~min}$ and then suspended in Hank's balanced salt solution (HBSS) at a concentration of $1.5 \%(\mathrm{v} / \mathrm{v})$. Immobilized FCS was adsorbed with SRBC (3 times, FCS: packed $\mathrm{SRBC}=9: 1(\mathrm{v} / \mathrm{v})$, at room temperature for $30 \mathrm{~min})$ to eliminate natural antibodies against SRBC. One volume of a human MNL suspension at a concentration of about $1 \times 10^{7}$ cells per $\mathrm{ml}$ of HBSS, two volumes of neuraminidase-treated SRBC $(1.5 \%)$ and one volume of FCS were mixed, incubated at $37^{\circ} \mathrm{C}$ for $15 \mathrm{~min}$, and then the mixture was spun at $200 \times g$ for $2 \mathrm{~min}$. The sediment was kept in ice for $1.5 \mathrm{hr}$, and then gently resuspended in HBSS, followed by layering upon the top of a FicollPaque solution and then centrifugation at $450 \times g$ for $30 \mathrm{~min}$. The cells at the interface were collected and washed with PBS, and designated as 'T-depleted cells.' The pellet was subjected to ACT treatment and washed with PBS, and designated as 'T-enriched cells.'

Human macrophages and monocytes were prepared utilizing the property of their adherence to a plastic surface ${ }^{10)}$ A human MNL suspension at a concentration of $1.0 \times 10^{7}$ cells per $\mathrm{ml}$ of RPMI-1640 medium containing $10 \%$ FCS was incubated in a tissue culture dish $\left(60 \times 15 \mathrm{~mm}\right.$, Falcon) at $37^{\circ} \mathrm{C}$ under a flow of $5 \% \mathrm{CO}_{2}$ in air. During the incubation the dish was gently shaken twice. The floating cells were collected and washed with PBS, and designated as 'Nonadherent cells.' The adhesive cells in the dish were washed twice with warm medium, detached from the dish with a rubber policeman ${ }^{11)}$ and washed twice with PBS, and designated as 'Adherent cells.'

Hemagglutination assay. On a microtiter plate (Cooke Engineering Co., Alexander, Va.), one drop of a mitogen sample was added to an equal volume of $0.05 \mathrm{M}$ phosphate-buffered saline ( $\mathrm{pH} 7.0$ ), followed by mixing with a drop of a $2 \sim 3 \%$ suspension of human, horse, chicken and rabbit erythrocytes with a micromixer (Kowakizai, Tokyo) for $1 \mathrm{~min}$. After $60 \sim 120 \mathrm{~min}$, hemagglutinating activity was determined by observation with the naked eyes.

Mitomycin C treatment. The separated leukocyte frac- 
tion was incubated with mitomycin $\mathrm{C}(\mathrm{mmc})(25 \mu \mathrm{g} / \mathrm{ml}$ culture) at $37^{\circ} \mathrm{C}$ in a humidified $\mathrm{CO}_{2}$ incubator under a flow of $5 \% \mathrm{CO}_{2}$ in air, and then washed three times with PBS.

Preparation of mitogen samples. The microorganisms examined were newly isolated and divided into four groups with respect to their habitats and the isolation procedures. The S-series bacteria were isolated from soil with trypto-soy medium (Eiken Chemical Co., Tokyo), the $\mathrm{H}$ and $\mathrm{V}$-series bactera from sea water with trypto-soy medium and thiosulfate-citrate-bile-sucrose (TCBS) medium (Eiken), respectively, and the A-series actinomycetes from soil with a medium ( $\mathrm{pH} 7.0)$ containing $1 \%$ glucose, $0.4 \%$ Daigo Polypepton, 0.2\% Ehrlich meat extract (Kyokuto), $0.2 \%$ yeast extract (Difco) and $2 \%$ agar. The $\mathrm{S}$-series strains and the $\mathrm{H}$ and $\mathrm{V}$-series strains were cultured with shaking at $30^{\circ} \mathrm{C}$ for $20 \mathrm{hr}$ in a medium (pH 7.0) containing $3 \%$ peptone and $0.5 \%$ yeast extract in tap water, and in a mixture of sea and tap water $(1: 1, \mathrm{v} / \mathrm{v})$, respectively. The A-series strains were cultured with shaking at $30^{\circ} \mathrm{C}$ for $48 \mathrm{hr}$ in a medium ( $\mathrm{pH} 6.0$ ) containing $0.5 \%$ Polypeptone, $0.1 \%$ yeast extract, $1.5 \%$ lactose and $0.05 \% \mathrm{MgSO}_{4}$ in $0.05 \mathrm{M}$ phosphate buffer. The culture broths were centrifuged at $10,000 \times g$ for $10 \mathrm{~min}$ to remove cells, except for those of the A-series strains, which were filtered through a filter paper (Toyo-Roshi, No. 2). The resulting supernatants were filtered through a membrane filter (HA $0.45 \mu \mathrm{m}$, Millipore Japan, Tokyo) and then used directly as mitogen samples.

\section{RESULTS}

\section{Screening of mitogen producing bacteria}

The first screening of mitogen-producing strains was carried out with twelve divided assays, each of which involved MNL from 12 different donors. Out of the culture filtrates of 419 strains (155 S-series, $96 \mathrm{~V}$-series, $78 \mathrm{H}$ series and $90 \mathrm{~A}$-series strains), 57 samples (21 $\mathrm{S}, 17 \mathrm{~V}, 13 \mathrm{H}$ and $6 \mathrm{~A})$ showed SI values exceeding 2. In the course of this screening, however, marked variation in the mitogen response of the test MNL to standard plant and microbial mitogens was observed. To avoid such variation due to differences in the MNL donors, a 2nd screening was carried out on the above 57 samples using MNL from three different donors with similar mitogenresponses, and in each assay the mitogenicity of selected samples was measured simultaneously. As shown in Table I, only ten samples showed average SI's exceeding 4, 8 of them being from $\mathrm{H}$-series bacteria.

None of these 57 samples showed hemagglutinating activity toward human (blood types $\mathrm{A}, \mathrm{B}$ and $\mathrm{O}$ ), horse, chicken or rabbit erythrocytes or human leukocyte agglutinating activity, though the control plant lectins agglutinated human lymphocytes.

Finally we chose three strains, H 49-4, H 52-

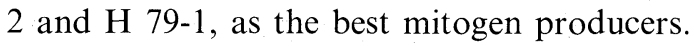
These three were all isolated from sea water and grew well on TCBS medium. Table II shows the taxonomical properties of these strains. According to Cowan, ${ }^{11)}$ the results suggest they are 'vibrios.'

\section{Table I. OCCurrence of Human Lymphocyte Mitogen-Producers among Microorganisms}

The $\left[{ }^{3} \mathrm{H}\right]$-thymidine uptake in the absence of a mitogen sample was $894 \pm 488 \mathrm{cpm}$ (mean \pm S.D.). The SI values for Con. A $(25 \mu \mathrm{g} / \mathrm{ml})$, PWM $(1 \mu \mathrm{g} / \mathrm{ml})$, PHA $(1 \mu \mathrm{g} / \mathrm{ml})$ and LPS $(5 \mu \mathrm{g} / \mathrm{ml})$ at the optimal dose were 53.7 , $28.8,95.5$ and 1.57 , respectively. The SI values for the media used for cultivating soil bacteria, marine bacteria and actinomycetes were $0.785,1.01$ and 0.885 , respectively.

No. of mitogenic strains

\begin{tabular}{|c|c|c|c|c|c|c|c|}
\hline \multirow[t]{2}{*}{ Microorganisms } & \multirow{2}{*}{$\begin{array}{c}\text { 1st screening } \\
\text { selected }\end{array}$} & \multicolumn{6}{|c|}{ average stimulation index (aSI) } \\
\hline & & 1 & $\sim 2$ & $\sim 3$ & $\sim 4$ & $\sim 5$ & $\sim 6$ \\
\hline S-series & 21 & 16 & 2 & 1 & 1 & 1 & 0 \\
\hline V-series & 17 & 9 & 6 & 2 & 0 & 0 & 0 \\
\hline $\mathrm{H}$-series & 13 & 0 & 1 & 4 & 3 & 3 & 2 \\
\hline A-series & 6 & 4 & 2 & 0 & 0 & 0 & 0 \\
\hline Total & 57 & 29 & 11 & 7 & 4 & 4 & 2 \\
\hline
\end{tabular}




\section{Animal species specificity}

The proliferative response of murine lymphocytes to the above three samples is shown in Table III. Con.A and LPS were used as standards of $\mathrm{T}$ cell mitogen and bone marrow derived lymphocyte (B cell) mitogen, respectively. Samples H 49-4, H52-2 and H 79-1 scarcely stimulated murine cells and sample $\mathrm{H}$ 52-2 was rather toxic for thymic cells. On the other hand, human MNL definitely proliferated in response to the three bacterial samples tested.

\section{Mitogen response of human MNL fractionated by plastic adherence}

To investigate the mechanism of the response of human MNL to a bacterial sample, human MNL were separated into two frac-

Table II. Taxonomical Properties of MitogenPRODUCING BACTERIA ISOLATED FROM SEA WATER

\begin{tabular}{lccc}
\hline Strain & H 49-4 & H 52-2 & H 79-1 \\
\hline Gram stain & - & - & - \\
Shape & Rod & Rod & Rod \\
Flagellation & Polar & Polar & Polar \\
Mobility & + & + & + \\
Effect of $\mathrm{O}_{2}$ & F.A. & F.A. & F.A. \\
OF test & $-{ }^{b}$ & F & F \\
Catalase & + & + & + \\
MR test & - & + & - \\
V-P test & - & - & - \\
NO ${ }_{3}^{-}$reduction & + & + & + \\
\hline$a$ & Facultative anaerobic. & & \\
( No effect on glucose. & &
\end{tabular}

tions, adherent and nonadherent cells. Sample H 52-2 was used throughout the following studies because of its high mitogenic activity and constant production. As shown in Table IV, the nonadherent cell fraction responded to Con.A, PHA and PWM, similar to the unfractionated MNL. However, an apparent decrease in the mitogenic response to sample $\mathrm{H}$ 52-2 was seen. On the other hand, the adherent cells did not proliferate in response to Con.A or sample H 52-2.

Mitogen response of human MNL separated by erythrocyte-rosette sedimentation

As shown in Table V, a markedly diminished response of the separated cells to the bacterial sample was seen; the response being about $1 / 6$ in $\mathrm{T}$-enriched cells and 0 in $\mathrm{T}$ -

Table III. Response of Murine and Human Lymphocytes to Mitogenic SAmples

Each value represents SI. The $\left[{ }^{3} \mathrm{H}\right]$-thymidine uptake in the absence of mitogens was $3470 \mathrm{cpm}$ in murine splenic cells, $491 \mathrm{cpm}$ in murine thymic cells and $417 \mathrm{cpm}$ in human peripheral blood MNL.

\begin{tabular}{lccc}
\hline & \multicolumn{2}{c}{ C57BL/6J mice } & \\
\cline { 2 - 3 } & Spleen & Thymus & $\begin{array}{c}\text { Human }^{b} \\
\text { peripheral } \\
\text { blood }\end{array}$ \\
\hline Con. A $(1 \mu \mathrm{g} / \mathrm{ml})$ & 16.4 & 32.9 & 53.7 \\
LPS $(25 \mu \mathrm{g} / \mathrm{ml})$ & 8.13 & 4.05 & 1.57 \\
H $49-4(5 \mu \mathrm{l})$ & 1.59 & 1.15 & 7.75 \\
H $52-2(5 \mu \mathrm{l})$ & 1.64 & 0.584 & 6.60 \\
H 79-1 $(5 \mu \mathrm{l})$ & 1.59 & 1.68 & 4.72 \\
\hline
\end{tabular}

a Average SI values for 4 mice.

$b$ Average SI values for 7 donors.

Table IV. Response of Human Plastic Surface Adherent and Nonadherent Cells to Mitogens

Each value represents the average radioactivity incorporated into cells (cpm).

\begin{tabular}{lccccc}
\hline & $\begin{array}{c}\text { Con. A } \\
(25 \mu \mathrm{g} / \mathrm{ml})\end{array}$ & $\begin{array}{c}\text { PWM } \\
(1 \mu \mathrm{g} / \mathrm{ml})\end{array}$ & $\begin{array}{c}\text { PHA } \\
(1 \mu \mathrm{g} / \mathrm{ml})\end{array}$ & $\begin{array}{c}\text { H 52-2 } \\
(5 \mu \mathrm{l})\end{array}$ & Control $^{d}$ \\
\hline Unfractionated $^{a}$ MNL & 29,500 & 13,700 & 39,500 & 8,020 & 521 \\
Nonadherent $^{a}$ & 36,300 & 12,100 & 50,100 & 5,700 & 491 \\
Adherent $^{b}$ & 3,290 & $c^{c}$ & $-{ }^{c}$ & 581 & 316 \\
\hline
\end{tabular}

a The average SI values for six experiments.

$b$ The average SI values for four experiments.

c Not determined.

$d$ Values in the absence of mitogens. 
Table V. Response of Human T-Enriched and T-Depleted Cells to Mitogen Samples

Each value represents the average radioactivity incorporated into cells (cpm) in eight assays.

\begin{tabular}{lccrrr}
\hline & $\begin{array}{c}\text { Con. A } \\
(25 \mu \mathrm{g} / \mathrm{ml})\end{array}$ & $\begin{array}{c}\text { PWM } \\
(1 \mu \mathrm{g} / \mathrm{ml})\end{array}$ & $\begin{array}{c}\text { PHA } \\
(1 \mu \mathrm{g} / \mathrm{ml})\end{array}$ & $\begin{array}{c}\text { M 52-2 } \\
(5 \mu \mathrm{l})\end{array}$ & Control $^{a}$ \\
& 46,400 & 23,400 & 51,500 & 3,770 & 559 \\
Unfractionated MNL & 36,300 & 14,500 & 42,400 & 1,060 & 428 \\
T-Enriched cells & 7,370 & 5,110 & 8,780 & 908 & 1,469 \\
T-Depleted cells & & &
\end{tabular}

a Values in the absence of mitogens.

depleted cells. On the other hand, the decreases in the responses of $\mathrm{T}$-enriched and $\mathrm{T}$-depleted cells proliferated in response to plant mitogens were not so great.

The mitogen response of $\mathrm{T}$-enriched and $\mathrm{T}$ depleted cells to sample $\mathrm{H}$ 52-2 was restored by mixing the two types of cells with each other (Figure 1). The highest response to sample $\mathrm{H}$ 52-2 was obtained with the mixture of $\mathrm{T}$-enriched and $\mathrm{T}$-depleted cells at a ratio of $75: 25$, with which $\left[{ }^{3} \mathrm{H}\right]$-thymidine uptake was rather higher than that in the case of unfractionated MNL. This result rules out the possibility that the reduction in the mitogen response was due to a loss or inactivation of the responding cells during the cell fractionation procedure.

\section{Effect of mitomycin $C$ treatment on the mito- genic response}

MNL were fractionated into three cell fractions by the combination of the plastic adherence method and the E-rosette sedimentation method, as described in Fig.2. The separated cell fractions were treated with mmc. As shown in Table VI, the proliferative response of the mmc-treated $\mathrm{E}-\mathrm{R}(+)$ cell fraction to Con.A, PWM and sample $\mathrm{H}$ 52-2 was markedly reduced compared to the response of an untreated culture. In the mixture of the E$\mathrm{R}(+)$ and adherent cell fractions, when the adherent cell fraction had been pretreated with $\mathrm{mmc}$, a high proliferative response to PWM and sample $\mathrm{H}$ 52-2 was observed, whereas, when the E-R $(+)$ cell fraction was pretreated with mmc, the response was markedly reduced, especially in the case of sample $\mathrm{H}$ 52-2.

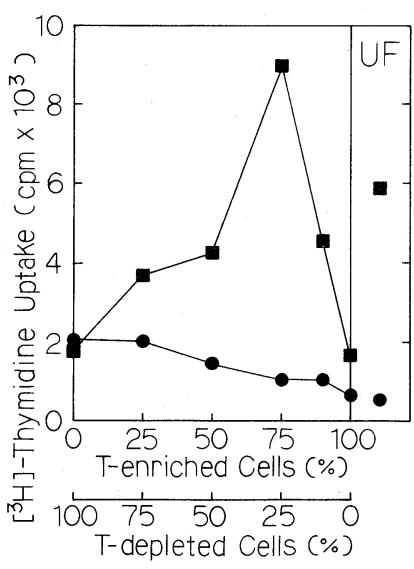

FIG. 1. Effect of Combining T-Enriched Cells with TDepleted Cells on the Mitogen Response.

The final cell concentration of the mixed culture of $T$ enriched and T-depleted cells was $5.0 \times 10^{5}$ cells per $\mathrm{ml}$. Incorporation of $\left[{ }^{3} \mathrm{H}\right]$-thymidine into the culture was measured in the presence of sample $\mathrm{H} \mathrm{52-2}(\boldsymbol{\square}, 5 \mu \mathrm{l})$ and in its absence (O). Each value is the square root of the product of the cpm values in two experiments (two MNL donors). UF denotes the culture of unfractionated cells.

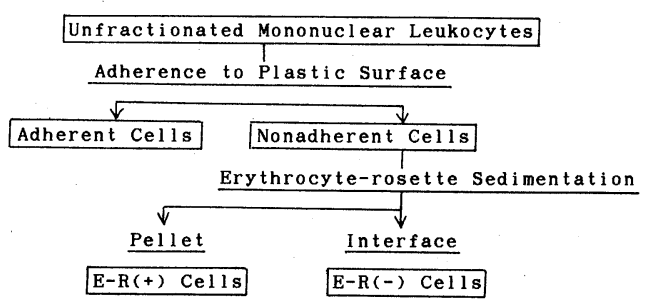

FIG. 2. Fractionation Scheme for Human Blood Mononuclear Leukocytes.

$\mathrm{E}-\mathrm{R}(+)$ and $\mathrm{E}-\mathrm{R}(-)$ cells refer to rosette formation with SRBC positive and negative cells, respectively.

On the other hand, in the mixed culture of the $\mathrm{E}-\mathrm{R}(+)$ and mmc-treated $\mathrm{E}-\mathrm{R}(-)$ cell fractions and that of the mmc-treated E-R $(+)$ and $\mathrm{E}-\mathrm{R}(-)$ cell fractions, the proliferative re- 
Table Vi. Effect of Mitomycin C Treatment of Human MnL Subsets on THE Mitogen Response

Each cell fraction of separated MNL subsets consisted of $2.5 \times 10^{5}$ cells per ml except for unfractionated MNL, which consisted of $5 \times 10^{5}$ cells per $\mathrm{ml}$. Each value represents the radioactivity incorporated into cells.

\begin{tabular}{|c|c|c|c|c|}
\hline & $\begin{array}{c}\text { Con. A } \\
(25 \mu \mathrm{g} / \mathrm{ml})\end{array}$ & $\begin{array}{c}\text { PWM } \\
(1 \mu \mathrm{g} / \mathrm{ml})\end{array}$ & $\begin{array}{c}\text { H } 52-2 \\
(5 \mu \mathrm{l})\end{array}$ & Control $^{c}$ \\
\hline Unfractionated MNL & 36,400 & 13,000 & 7,760 & 1,020 \\
\hline $\mathrm{E}-\mathrm{R}(+)$ & 30,500 & 7,920 & 728 & 174 \\
\hline $\mathrm{E}-\mathrm{R}(+)_{\mathrm{mmc}}^{b}$ & 5,420 & 827 & 85 & 80 \\
\hline $\mathrm{E}-\mathrm{R}(+)+\mathrm{A}_{\mathrm{mmc}}$ & 40,100 & 11,600 & 5,960 & 175 \\
\hline $\mathrm{E}-\mathrm{R}(+)_{\mathrm{mmc}}+\mathrm{A}^{a}$ & 15,000 & 7,830 & 1,850 & 381 \\
\hline $\mathrm{E}-\mathrm{R}(+)+\mathrm{E}-\mathrm{R}(-)_{\mathrm{mmc}}$ & 30,800 & 7,860 & 4,510 & 197 \\
\hline $\mathrm{E}-\mathrm{R}(+)_{\mathrm{mmc}}+\mathrm{E}-\mathrm{R}(-)$ & 14,000 & 5,330 & 5,180 & 417 \\
\hline
\end{tabular}

a Adherent cell fraction.

$b$ Treated with mitomycin C.

c Values in the absence of mitogens.

sponse to PWM and sample $\mathrm{H}$ 52-2 was about a half of that in the case of unfractionated MNL.

\section{DISCUSSION}

From the results of our screening, it is concluded that marine bacteria, especially marine vibrios, are rich sources of mitogenic substances for human lymphocytes. Oishi et al. systematically screened hemagglutinating activity in microorganisms and showed that highly active strains were present in marine vibrios. ${ }^{13)}$ Mitogen samples from our selected strains did not agglutinate mammalian erythrocytes, in which they differ from bacterial lectins. They also differ from plant mitogenic lectins. They are human specific, whereas plant mitogens display broad species specificity.

Human lymphocyte mitogens of microbial origin were known to be distributed predominantly in pathogenic strains as toxic substances or to be components of the cell wall or cell membrane; i.e., pyrogenic exotoxin, ${ }^{14)} \mathrm{M}$ protein ${ }^{15)}$ and lipoteichoic acid ${ }^{16)}$ of Streptococcus pyogenes, pyrogenic exotoxin, ${ }^{17)}$ enterotoxin $\mathrm{B},{ }^{18)}$ toxic shock toxin, ${ }^{19)}$ protein $A,{ }^{20)}$ Cowan $\mathbf{I},{ }^{21)}$ peptidoglycan, ${ }^{22)}$ teichoic acid $^{23)}$ and cytoplasmic membrane ${ }^{24)}$ of Staphylococcus aureus, water soluble mitogen $^{25)}$ of Nocardia opaca, polysaccha- ride $^{26)}$ of Candida albicans, protein fraction of cell wall ${ }^{27)}$ of Salmonella typhimurium, extracellular slime layer ${ }^{28}$ ) and galactosephilic lectin $^{29)}$ of Pseudomonas aeruginosa and culture broth $^{30)}$ of Mycoplasma arthritidis. Rare exceptions are mycelia ${ }^{31)}$ and bestatin ${ }^{32)}$ of nonpathogenic Streptomyces. The present human lymphocyte mitogens were not toxic to mice, so far as examined at the level of $5 \mathrm{ml}$ i.p. injection per mouse, and obtained from marine bacteria which do not shown human or fish pathogenicity.

The present mitogens have not yet been purified from the culture filtrate. However, it is considered to be a low molecular weight substance because most of the activity passed through a cellulose tube and hollow fiber $\mathrm{HI}$ (Asahi Chemical Industry, Co., Tokyo), and it was found to have a $M_{\mathrm{r}}$ in the range of $1000 \sim 1300$ on Sephadex G-50 column chromatography. It could not be extracted from the culture filtrate with $n$-butanol, ethyl acetate or benzene at $\mathrm{pH} 3,5$ or 12 , and hardly adsorbed to DEAE Sephadex in the $\mathrm{pH}$ range of $5.0 \sim 9.0$. Heating at $60^{\circ} \mathrm{C}$ for $10 \mathrm{~min}$ caused. a little decrease in the mitogenic activity whereas that at $80^{\circ} \mathrm{C}$ resulted in a $55 \%$ decrease. The remaining activity was quite stable and heating at $100^{\circ} \mathrm{C}$ had no further effect on the activity.

With the exception of bestatin, the microbial 
mitogens mentioned above have high molecular weights and are heat labile. In these points, the present mitogen is considered to be a novel one.

The mitogen response of human lymphocytes to plant mitogens requires cell-cell interaction; i.e., the proliferative response of human $\mathrm{T}$ cells to Con.A only occurs in the presence of monocytes, ${ }^{33)}$ and the stimulation by PWM of human B cells to proliferate and differentiate into immunoglobulin secreting cells requires both $\mathrm{T}$ cells ${ }^{34)}$ and monocytes. ${ }^{35)}$ As to cell-cell interaction in the mitogen response to bacterial sample $\mathrm{H} 52-2$, it is not obvious that macrophages and monocytes play crucial roles, because depletion of adherent cells from a human MNL culture resulted in only a little decrease in the response. However, a small number of macrophages and monocytes contaminated in the nonadherent cell preparation may fully help the proliferative response of the lymphocytes. The present results indicate that $T$ cells play a major role in the mitogen response, and the full response requires cell-cell interaction between $\mathrm{T}$ cells and other cells. The results of the experiment involving mmc treatment indicate that the cells proliferating in response to sample $\mathrm{H}-52-2$ form 2 classes; $\mathrm{T}$ cells and non- $\mathrm{T}$ lymphocytes. In the former case, non-T lymphocytes or macrophages (monocytes) play an accessory role in proliferation of $\mathrm{T}$ cells, and in the latter case, $T$ cells play an accessory role in the proliferation of non-T lymphocytes.

\section{REFERENCES}

1) N. Sharon, Adv. Immunol., 34, 213 (1983).

2) I. Gery, J. Kruger and S. Z. Spiesel, J. Immunol., 108, 1088 (1972).

3) A. S. Kong and S. I. Morse, J. Exp. Med., 145, 151 (1977).

4) K. Ariizumi, K. Oishi and K. Aida, J. Gen. Appl. Microbiol., 26, 239 (1980).

5) A. Böyum, Scan. J. Clin. Lab. Invest., 21 (Suppl., 97), 1 (1968).

6) R. Dulbecco, J. Exp. Med., 99, 169 (1954).

7) G. Janossy and M. F. Greaves, Clin. Exp. Immunol., 9, 483 (1971).

8) M. Jondal, G. Holm and H. Wigzell, J. Exp. Med.,
136, 207 (1972).

9) U. Galili and M. Schlesinger, J. Immunol., 112, 1628 (1974).

10) R. Evans, J. Reticuloendocrinol. Soc., 8, 571 (1970).

11) S. T. Cowan, "Manual for the Identification of Medical Bacteria," 2nd Ed., Cambridge Univ. Press, 1974.

12) E. R. Unanue, Nature, 218, 36 (1968).

13) K. Oishi, S. Yokoshima, T. Tomiyama and K. Aida, Appl. Environ. Microbiol., 38, 169 (1979).

14) P. M. Schlievert, D. J. Schoettle and D. W. Watson, Infect. Immun., 27, 276 (1980).

15) H. Knöll, O. Kühnemund and J. Havlicěk, Immunobiol., 156, 537 (1979).

16) E. H. Beachey, J. B. Dale, S. Grebe, A. Ahmed, W. A. Simpson and I. Ofek, J. Immunol., 122, 189 (1979).

17) P. M. Schlievert, D. J. Schoettle and D. W. Watson, Infect. Immun., 25, 1075 (1979).

18) D. L. Peavy, W. H. Adler and R. T. Smith, J. Immunol., 105, 1453 (1970).

19) S. E. Calvano, F. W. Quimby, A. C. Anthony, R. F. Reiser, M. S. Bergdoll and P. Dineen, Clin. Immunol. Immunopathol., 33, 99 (1984).

20) A. Forsgren, A. Svedjelund and H. Wigzell, Eur. J. Immunol., 6, 207 (1976).

21) J. Pryjma, J. Munoz, R. M. Galbraith, H. H. Fudenberg and G. Virella, J. Immunol., 124, 656 (1980).

22) R. Dziarski and A. Dziarski, Infect. Immun., 23, 706 (1979).

23) R. Dziarski, A. Dziarski and A. I. Levinson, Int. Archs. Allergy Appl. Immunol., 63, 383 (1980).

24) H. Takada, Y. Hirachi, H. Hashizume and S. Kotani, Microbiol. Immunol., 25, 317 (1981).

25) J. Brochier, C. Bona, R. Ciorbaru, J. P. Revillard and L. Chedid, J. Immunol., 117, 1434 (1976).

26) E. Piccolella, G. Lombardi and R. Morelli, J. Immunol., 125, 2082 (1980).

27) M. B. McChesney, C. J. Froelich, J. L. Cantrell and R. C. Williams, Jr., Cell. Immunol., 93, 83 (1985).

28) M. Papamichail, G. Dimitracopoulos, G. Tsokos and J. Papavassiliou, J. Infect. Dis., 141, 686 (1980).

29) Y. Sharabi and N. Gilboa-Garber, FEMS Microbiol. Lett., 5, 273 (1979).

30) R. A. Daynes, J. M. Novak and B. C. Cole, J. Immunol., 129, 936 (1982).

31) B. F. Maier, D. P. Baron, H. Bockhorn, H. Drautz, J. Langharig and W. G. Bessler, Immunobiol., 163, 427 (1982).

32) M. Ishizuka, J. Sato, Y. Sugiyama, T. Takeuchi and H. Umezawa, J. Antibiot., 33, 653 (1980).

33) R. Palacios, Immunol. Rev., 63, 72 (1982).

34) T. Hirano, T. Kuritani, T. Kishimoto and Y. Yamamura, J. Immunol., 119, 1235 (1977).

35) S. A. Rosenberg and P. E. Lipsky, J. Immunol., 122, 926 (1979). 